\title{
14 THE GREAT ZIMBABWE MONUMENTS AND CHALLENGES IN AFRICAN HERITAGE MANAGEMENT
}

\section{Edmore Dube $^{1}$}

\section{INTRODUCTION}

The chapter examines how colonial policies have affected the Shona forefathers' and their Remba cousins' rites and rituals within the Great Zimbabwe Monuments grounds. In proposing Jewish, Arabic, Persian, Portuguese, Chinese or Indian as opposed to African origins of the structures, the colonial discourse has effected regime change at the monuments. ${ }^{2}$ Originating with missionaries and perpetuated by the British colonialist politician Cecil John Rhodes, who employed pseudo-archaeologists armed with the results supporting a case for foreign origins before the excavations commenced, the colonial ideology negating African architectural capacity also includes items such as a 1938 tourism and monuments brochure that includes the shadowy image of the Queen of Sheba against the monuments' conical tower. ${ }^{3}$ Though some groups may have resisted colonial classification, the Remba seem to have given in to the "superior discourse" in the form of the Judeo-Christian template (evaluating $^{4}$ everything using Jewish and Christian values). The dominant discourse has been such that associating with Jewish or Christian traditions is ranked superior to all other traditional associations tenable in Zimbabwe. Some Remba have even found it prudent to exploit the slightest similarities with Jews to escape the stigma which would accrue from retaining association with "warring" Arabs.

The Remba are a Shona-speaking group found in clusters throughout Zimbabwe with some concentration around Great Zimbabwe, though Mberengwa District is thought to be their spiritual home. ${ }^{5}$ They follow dietary laws, circumcision rituals and genetic configurations similar to Jews and Arabs, and scholarly opinion differs on whether such similarities are of Jewish or Arab origin.

1 Edmore Dube holds a PhD in Islamic Studies from the Department of Philosophy and Religious Studies, Great Zimbabwe University.

2 Bent JT. 1892. "The Ruined Cities of Mashonaland, and Explorations in the Country", Proceedings of the Royal Geographical Society 14(5):42.

3 "The British Museum: The Wealth of Africa Great Zimbabwe Students' Worksheets". Online at: https://www.britishmuseum.org/pdf/GreatZimbabwe_ StudentsWorksheets.pdf

4 Mazarire GC. 2013. "Mberengwa, Zimbabwe - Home to the Lemba Tribe. Are they the descendants of Yemenite Jews?" Unpublished paper presented at the Historical Dimensions of Development in the Midlands Seminar, Fairmile Hotel, Gweru, 2001.

5 Mativha MER. 1992. The Basena, Vamwenye, Balemba. Johannesburg: Morester, 47. 
However, the genetic similarity is only male oriented leading to a scholarly consensus that their mothers are Shona. ${ }^{6}$ The chapter will examine this argument in due course, but of critical importance is the fact that the Remba themselves are divided on their paternity, which is also a critical issue in the intangible heritage debate. The existence of Arab material culture together with curved objects symbolising circumcised male organs attributed to the Remba at Great Zimbabwe further complicates their relationship with Arabian origins, just as it does their roles in the building and use of Great Zimbabwe. Even worse, the Remba have not only lost their intangible heritage in the ensuing confusion, but they have also been excluded from any say regarding the monuments, which have been expropriated by the successive governments.

The challenges in heritage management are a result of Western-type legal statutes improperly constituted to "disinherit" the owners of the shrine in favour of the political elite. ${ }^{7}$ The political elite are either directly or indirectly (complicit) in collusion with some missionaries and education authorities in appropriating heritage sites for their own benefit. The Solomonic legend has been used as a superior ideological tool to discredit any legitimate local claims. Furthermore, this Solomonic legendary motif within the "Judeo-Christian template" has augmented the non-African origins of the controversy, which resulted in acute nationalism struggling against colonialism. The chapter begins with an examination of the non-African origins controversy before moving on to focus on the African origins and the shrine's religious significance. From there it highlights Arab-Remba interaction, after which it addresses colonialism and nationalism in conflict and the Solomonic legend with its inherent elements of Jewish-Arab conflict. The chapter concludes that the Judeo-Christian template, colonialism and Western-type laws have disinherited the locals of which the Remba serve as an example. Since the heritage managers are fully aware of this, they are in an awkward position in which they have to manage heritage against their consciences. Heritage managers have written extensively to show that heritage should instead be managed for the locals, with the locals. ${ }^{8}$

\section{THE NON-AFRICAN ORIGINS CONTROVERSY}

The Great Zimbabwe Monuments are a disputed Iron Age settlement comprising dry bond stone structures located seventeen miles southeast of

6 See Beach DN. 1980. The Shona and Zimbabwe 900-1850. Gweru: Mambo; Mandivenga EC. 1983. Islam in Zimbabwe. Gweru: Mambo.

7 Mawere M, Sagiya ME and Mubaya TR. 2012. “Convergence of Diverse Religions at Zimbabwe Heritage Sites: The Case of Great Zimbabwe National Monument", International Research Journal of Arts and Social Sciences 1(2):23.

8 See Ndoro W. 2005. The Preservation of Great Zimbabwe: Your Monument, Our Shrine. ICCROM Conservation Studies 4. Rome, Italy; Matenga E. 2011. “The Soapstone Birds of Great Zimbabwe. Archaeological Heritage, Religion and Politics in Postcolonial Zimbabwe and the Return of Cultural Property", Studies in Global Archaeology 16. Uppsala: Uppsala University. 
the city of Masvingo in central Zimbabwe. The monuments are 159 miles from the Zimbabwean capital of Harare, 300miles south of the Zambezi River and 250 miles west of the Indian Ocean. ${ }^{9}$ They are the largest and most magnificent of the more than 250 similar structures scattered across the adjacent Mozambique, South Africa, Botswana and Zimbabwe - collectively known as the Zimbabwe Culture sites. ${ }^{10}$ The Great Zimbabwe monuments were strategically located on the southern edge of the so-called Central Plateau, in a commanding position to take advantage of the costal trade with the Swahili and the Arabs, ${ }^{11}$ as the most dominant authority south of the Zambezi for 250 years. ${ }^{12}$ It was also a metropolitan city of the "ancient" miners. ${ }^{13}$ Archaeologist Innocent Pikirayi argues that the term "ancient" has generally been used by antiquarians at the turn of the twentieth century (for example, by Theodore Bent 1892, Richard Hall 1905) to disconnect the present day Karanga locals from the builders of Great Zimbabwe, as an effort at silencing later history. ${ }^{14}$ Such silencing has left indigenous people angry. ${ }^{15}$ Through the utilisation of vashambadzi (trade agents), the Great Zimbabwe state was able to maintain links with traders from Kilwa on the Tanzanian coast, as well as West Africa, Persia and China, ${ }^{16}$ and its decline may have been due to the shift of gold trade to the north. ${ }^{17}$

The non-African theory of the origin of the monuments is a Eurocentric assumption based on Western prejudice against the African intellectual and architectural capacity. ${ }^{18}$ European travelers were astounded by such an elegant civilisation in the heart of Africa and they refused to accept indigenous architectural capacity for such magnificent construction. ${ }^{19}$ The perception, partly sponsored by Christian missionaries and partly by the British colonists, went unchallenged for over thirty years following its initial publication by

9 Carroll ST. 1988. "Solomonic Legend: The Muslims and the Great Zimbabwe", The International Journal of African Historical Studies 21(2):223-247, (233).

10 Carroll, "Solomonic Legend", 233; Ampim M. 2004. "Great Zimbabwe: A History Almost Forgotten" (April 2004 presentation delivered in Toronto, Canada, sponsored by the G.O.D. Collective); Pikirayi I. 2016. “The True Story of Great Zimbabwe", New Zimbabwe, 8 March.

11 Beach DN. 1980. The Shona and Zimbabwe 900-1850. Gweru: Mambo; Ndoro W. 1997. "Great Zimbabwe", Scientific American 95.

12 Pikirayi I. 2013. "Great Zimbabwe in Historical Archaeology: Reconceptualising Decline, Abandonement, and Reoccupation of an Ancient Polity, A.D. 1450-1900", Historical Archaeology 47(1):26-37, (27).

13 Hall RN and Neal WG. 1902. The Ancient Ruins of Rhodesia. London: Methuen.

14 Pikirayi, "Great Zimbabwe in Historical Archaeology", 33.

15 Fontein J. 2016. The Silence of Great Zimbabwe: Contested Landscapes and the Power of Heritage. London and New York: Routledge.

16 "Ancient Zimbabwe - The Great Zimbabwe Ruins". Online at: http://www. victoriafalls-guide.net/ancient-zimbabwe.html

17 Pikirayi, "The True Story of Great Zimbabwe".

18 Pikirayi I. 2012. "Peter Garlake (1934-2011), Great Zimbabwe and the politics of the past in Zimbabwe", Azania: Archaeological Research in Africa 47(2):224.

19 Carroll, "Solomonic Legend", 233. 
explorer Karl Mauch. ${ }^{20}$ In 1871, Karl Mauch, a German national, categorised the monuments as part of the family of Semitic structures, claiming - with religious overtones - that the structures were modelled on Solomon's temple on Mount Moriah overlooking the Ophir gold mines. This Solomonic theoretical postulation originating from a literary genre of travel and adventure stories was subsequently mistaken by unsuspecting European audiences as actually representing Solomon's reign at the Great Zimbabwe. ${ }^{21}$ As Zimbabwean heritage specialist and former site manager of the Great Zimbabwe World Heritage property, Webber Ndoro aptly puts it: "A sample of wood from a lintel bolstered Mauch's rapid assessment: it smelled like his pencil, therefore it was cedar and must have come from Lebanon ... This attitude was pervasive in colonialist Africa: the continent had no history, no sophistication; its people and tribes were unchanging, unable to develop, culturally barren."22

The physical presence of Solomon at Great Zimbabwe was strengthened by a further comparison of the monuments on the plain to supposed palace lodgings of the Queen of Sheba when she visited Jerusalem during the reign of Solomon, "which must have been replicated here by a civilized mind". ${ }^{23}$ The Rhodesia ${ }^{24}$ Department of Tourism strengthened the Solomonic legend through its advertisement brochures. As noted earlier, a travel poster of 1938 presented the monuments with a shadowy picture of the Queen of Sheba on the walls of the conical power. ${ }^{25}$ The poster represented the official colonial position regarding the history of the monuments. Later travelers, disputing both local acumen and legends based on the Bible, suggested Portuguese, Arab, Chinese, Persian or Indian architectural involvement. ${ }^{26}$ This was due to the proximity of the Arabs in the Zambezi valley and the Portuguese on the coast of the Indian Ocean, as well as artefacts of Arab, Chinese, Persian and Indian origin found at the site. These included a fourteen century-Arab copper coin with the seal of Hasan ibn Sulaiman, the sultan of Kilwa (1320-1330 CE) on the Tanzanian coast, glass beads and porcelain from China (mostly from the Ming Dynasty - 1368 to 1644 CE) and Persia. ${ }^{27}$ Ceramic ethno-archaeology was used to develop models and chronology of these pre-historic events, ${ }^{28}$ though much still needs to be done to improve the description of Great Zimbabwe ceramics. ${ }^{29}$ Parallels were drawn

20 Ampim, "Great Zimbabwe: A History Almost Forgotten".

21 Carroll, "Solomonic Legend", 238.

22 Ndoro, "Great Zimbabwe", 98.

23 Ampim, "Great Zimbabwe: A History Almost Forgotten".

24 Rhodesia was the colonial name of Zimbabwe.

25 "The British museum: The Wealth of Africa Great Zimbabwe Students" Worksheets". Online at: https://www.britishmuseum.org/pdf/GreatZimbabwe_ StudentsWorksheets.pdf

26 Bent, "The Ruined Cities of Mashonaland", 242.

27 Ndoro, "Great Zimbabwe", 98.

28 Nyamushosho RT. 2014. "Ceramic Ethnoarchaeology in Zimbabwe”, International Research Journal of Arts and social Science 3(2):17-18.

29 Pikirayi I and Chirikure S. 2011. "Debating Great Zimbabwe”, Azania: Archeological Research in Africa 46(2):225. 
with the stone structures of the Indian golden city of Myosore of the Vijayanagar kingdom. ${ }^{30}$ This new parallel made further connections between gold and God by associating gold mining with a religious shrine.

Cecil John Rhodes, whose agenda would have been greatly enhanced by looking down upon the indigenous African population and rejecting any significant architectural acumen among them, sponsored James Theodore Bent, a member of the British Association of Science, who was not a qualified archaeologist, to excavate at the Great Zimbabwe Monuments. As might have been anticipated of a paid non-professional, Bent maintained that the artefacts were of foreign origin, Semitic in nurture and most likely Arabian. ${ }^{31}$ This position was sustained ten years later by British archaeologist, Richard Hall, who concluded that the ruins reflected the culture of more civilised races. ${ }^{32}$ He relegated the African occupation of the settlement to a later date and busied himself removing the layers that told the African story as a later contamination of civilisation. This ideological position remained official throughout the colonial period $(1890-1979){ }^{33}$

\section{AFRICAN DISCOURSES OF GREAT ZIMBABWE}

African discourses celebrate the Great Zimbabwe Monuments as an African contribution to world civilisation. These monuments have tremendous cultural, political and scientific significance. ${ }^{34}$ They were proclaimed a national heritage site by the colonial government in 1937, and Zimbabwean nationalists saw them as a pillar of strength, ${ }^{35}$ and all colonial efforts to thwart nationalism through 'alienising' monuments failed. ${ }^{36}$ This was clear in the renaming of the Zimbabwe National Party from African National Party and the formation of Zimbabwe African People's Union in 1961, Zimbabwe African National Union in 1963 and the adoption of the name "Zimbabwe" at independence in 1980. This Afrocentric view got its initial boost in 1905 through the work of the English archaeologist David Randall-MacIver.

Randall-MacIver, who carried out the first scientific archaeological excavations of the monuments and paid close attention to the mud dwellings on the site was the first to declare the monuments to be "unquestionably African in every detail" ${ }^{37}$ This officially-unacceptable conclusion led to the restriction of archaeologists from the site for quite some time. However, the British

30 Carroll, “Solomonic Legend”, 238.

31 Bent, "The Ruined Cities of Mashonaland", 238.

32 Hall, The Ancient Ruins of Rhodesia.

33 Garlake P. 1973. Great Zimbabwe: New Aspects of Archaeology. London: Thames \& Hudson.

34 Ndoro, The Preservation of Great Zimbabwe: Your Monument, Our Shrine, 62-71.

35 "Ancient Zimbabwe - The Great Zimbabwe Ruins".

36 Pikirayi, "Peter Garlake (1934-2011)", 224.

37 Randall-MacIver D. 1906. "The Rhodesia Ruins: Their probable origins and significance", The Geographical Journal 27(4):325-336. 
archaeologist Gertrude Canton-Thomas was allowed access to the ruins in 1929. She confirmed that the monuments were of African origin with respect to artefacts, nearby dwellings and oral tradition. ${ }^{38}$ Archaeologist Peter Garlake, who was a senior inspector of the monuments during the colonial era, must have surprised the establishment by negating the foreign origins position he was employed to defend and market. ${ }^{39}$ Instead, he defended the indigenous origin of the monuments on account of the homogeneity of the structures with surrounding styles, and for that he was exiled in $1970 .{ }^{40}$ Scott T Carroll aptly notes that the problem lay in that "the suggestion that Black African constructed such grandiose building as the Great Zimbabwe assails tremendous prejudice." 41 Zimbabwean archaeologist Innocent Pikirayi lays blame for the Great Zimbabwe site and landscape contest on lack of representation of local history in literature, museum displays, archaeological narratives and management reports. ${ }^{42}$

\section{Religious symbolism and significance}

The Hill Complex (acropolis) was the symbol of royalty and religion, ${ }^{43}$ and the elegant stone structures represented prestige and status. ${ }^{44}$ Standing on an elevated place, eighty meters above the ground, it is the oldest structure on the site that gradually spread to the valley in phases II and III. ${ }^{45}$ Part of the complex had steatite upright posts topped with soapstone birds interpreted as symbols of authority and rituality. The secluded, high-level complex was a symbolic show of authority, as well as to preserve the royal privacy. ${ }^{46}$ The sacred enclosure by the king's hill residence, the location where the bird sculptures were found, was excluded from the generality of the people, leaving it as a preserve for the selected practitioners. At this site the king patronised the territorial spirits symbolised by the bird sculptures that lent legitimacy to the state. Spirit mediums have continued to visit the site through the colonial period to the present. It is clear that the sanctuary had a political and territorial aura, though Matonjeni and Njelele shrines in Matopos were regarded as more sacred. ${ }^{47}$

38 Caton-Thompson G. 1931. The Zimbabwe Culture: Ruins and Reactions. Clarendon.

39 Garlake, Great Zimbabwe.

40 Pikirayi, "Peter Garlake (1934-2011), 224.

41 Carroll, "Solomonic Legend", 233.

42 Pikirayi, "Great Zimbabwe in Historical Archaeology", 26.

43 "Great Zimbabwe", Enyclopaedia Britannica. Online at: http://www.britannica. com/place/Great-Zimbabwe

44 Pikirayi, "Great Zimbabwe in Historical Archaeology", 26.

45 Chirikure S, Bandama F, Chipunza K and Ndoro W. 2016. "Seen but not told: Remapping Great Zimbabwe using Archival data, Satellite Imagery and Geographical Information Systems", Journal of Archaeological Method and Theory, 15.

46 “Great Zimbabwe (Eleventh-Fifteenth Centuries)". 2001. Online at: http://www. metmuseum.org/toah/hd/zimb/hd_zimb.htm

47 Ndoro, The Preservation of Great Zimbabwe: Your Monument, Our Shrine, 68. 
At the centre of the religious system was Mwari, the God of fertility, who communicated to the people through the spirit mediums. Despite the collapse of the state in the fifteenth century, the religious ceremonies continued into the nineteenth century. ${ }^{48}$ Zimbabwean archaeologist Roger Summers notes that "Dzimbabwe was a place sacred to the chief and his ancestors where formal supplications were made to the Great God Mwari in times of dire tribal need: drought, cattle diseases and human epidemics". ${ }^{49}$ Many myths attest to the religious value of the Great Zimbabwe monuments to this day. Even Karl Mauch witnessed the religious awe the shrine provoked from locals - a religious value that may have helped it make onto the UNESCO list. ${ }^{50}$

African and African American historian Manu Ampim, translates the term zimbabwe as the "venerated house", the "ritual seat of the king" and the "home or grave of a chief". ${ }^{51}$ The Zimbabwean archaeologist Edward Matenga argues that the interpretation associating zimbabwe with the burial place of chiefs was due to the fact that kings were buried in stone structures. ${ }^{52}$ Greater veneration in Shona kingdoms went to the graves and ancestors of the chiefs. Such ancestors were referred to mhondoro (territorial spirits). ${ }^{53}$ The rain-supplication ceremonies included the sweeping of the graves of former chiefs as an integral part. ${ }^{54}$ Great Zimbabwe, therefore, implies a great house of the ancestors of the Shona people, the guardians of the land..$^{55}$ Discoveries of the ceremonial battle spear and axes in the same place enhanced the ritual nature of the enclosure. Innocent Pikirayi and Shadreck Chirikure maintain that material culture found inside the enclosure reflect what they were used for. ${ }^{56}$ The ritual spearhead, iron gongs and soapstone bird effigies attest to the presence of a ruling elite, centralising religion for the benefit of power and order. ${ }^{57}$ Cecil John Rhodes' Ancient Ruins Company effectively ended this rich practice, putting the site management into perpetual dispute.

\section{Arab and Remba peoples in the hinterland}

But the indigeneity of the Great Zimbabwe monument has a lineage that is intricately connected with the Arab and Remba peoples who inhabited the

48 "Ancient Zimbabwe - The Great Zimbabwe Ruins".

49 Summers R. 1971. Ancient Ruins and Vanished Civilisations of Southern Africa. Cape Town: Gothic Priniting Company, 2.

50 Mawere, Sagiya and Mubaya, "Convergence of Diverse Religions", 22-31.

51 Ampim, "Great Zimbabwe: A History Almost Forgotten".

52 Matenga, "The Soapstone Birds of Great Zimbabwe", 123-131.

53 Schoffeleers JM (ed). 1979. Guardians of the Land: Essays on Central African Territorial Cults. Gweru: Mambo.

54 Dube E. 2013. A Tradition of Abstinence and Ritual Identity: The Ruling Sadiki Remba of Mposi in Mberengwa. Lambert: Lambert Academic.

55 Ampim, "Great Zimbabwe: A History Almost Forgotten".

56 Pikirayi and Chirikure, "Debating Great Zimbabwe", 222.

57 Matenga E. 1998. The Soapstone Birds in Zimbabwe: Symbols of a Nation. Harare: African Publishing Group, 19. 
region. ${ }^{58}$ Within the broader boundaries of the ancient Zimbabwe state, there was a symbiotic relationship between Arabs and Shona middlemen. ${ }^{59}$ From this relationship emerged the name Remba, derived from chilemba, a turban worn by Muslims and their local admirers, including African converts to Islam. ${ }^{60}$ The Arabs penetrated Zimbabwe from the East African coast during the era of the Great Zimbabwe state, which rose, peaked and collapsed before $1500 \mathrm{CE} .{ }^{61}$ These Arabs intermarried with the coastal and interior people. Islam spread through this direct contact with the Arabs, as a result. The Muslim activities in the vast Mutapa Empire (a successor to the Great Zimbabwe state) were gradually affected by the Portuguese establishment of Sofala in $1505 .{ }^{62}$

Arab wares and architecture were adopted as standard in some settlements in the Zambezi valley resulting in a hybrid culture. Beach observes that "in this culture, Islam became a dominant religion, and spread from the Arabs to the African people along with some Arabic." 63 Barbosa confirmed that some Muslims at "Sofala are black men, some olive, and use the tongue of the land." 64 The Shona Muslims acted as vashambadzi (middlemen) buying gold at a cheaper price on the Plateau to be sold at a competitive price at the coast. ${ }^{65}$ From their large settlement at Sena, the Remba earned the contextual names Vasena (of Sena) and Vashavi (traders). ${ }^{66}$ During the colonial period the Shona-speaking Remba, were "lumped together with Muslim Indians under the general classification of mwenye." 67

As trade on the Central Plateau was controlled from Great Zimbabw, some of the Islamised "Shona-speaking peoples" spread to Great Zimbabwe, and their presence at Great Zimbabwe affected the local customs. ${ }^{68}$ The Zimbabwean scholar of Islamic Studies Ephraim Chikakano Mandivenga maintains that, "It appears that with the coming of Muslim traders the whole area was turned over

58 Dube E. 2014. “Ephraim Chikakano Mandivenga and Tudor Parfitt: Two Scholars at Cross Roads? Reflections on the Remba Origins", Journal of International Academic Research for Multidisciplinary 2(9):306-319.

59 Beach, The Shona and Zimbabwe 900-1850, 417.

60 Gideon S. 2003. Community and Conscience: the Jews in Apartheid South Africa. New York: Brandeis University Press, 178.

61 Mandivenga, Islam in Zimbabwe, 1.

62 Mandivenga EC. 1992. "Muslims and the Pre-colonial History of Zimbabwe", Journal Institute of Muslim Minority Affairs 13:99-115, (99).

63 Beach, The Shona and Zimbabwe 900-1850, 25; Alpers EA. 2000. "East Central Africa", in Levitzion N and Pouwels RL (eds). The History of Islam in Africa. Athens: Ohio University Press, 303.

64 Quoted by Beach, The Shona and Zimbabwe 900-1850, 107.

65 Beach, The Shona and Zimbabwe 900-1850, 40.

66 Muhammad bin-Dohry. 2011. "Great Zimbabwe and the Lemba connection," Online at: http://www1.herald.co.zw; Stayt HA. 1931. "Notes on the Balemba", Journal of the Royal Anthropological Institute 61:231-238.

67 Beach, The Shona and Zimbabwe 900-1850, 108. "Mwenye" is a Remba praise name which David Beach argues denotes Islamic origin, which is why the Remba were officially classified with Muslims.

68 Mandivenga, Islam in Zimbabwe, 2. 
to Islamic influence to a large extent. Besides, many of the tribesmen apparently adopted such Muslim names as Ali, Moosa, Kassim, Mustafa, Adam, Yusuf. These indigenous people are today identified as the Varemba". ${ }^{69}$ Though Mandivenga may be exaggerating the Islamic influence at the Great Zimbabwe capital, some Remba people inhabit the area around Great Zimbabwe to this day and there is evidence of Muslim presence dating a few centuries back. ${ }^{70}$ The Remba use tribal names, such as Madi, Sadiki, Hasani, Hamisi, Haji, Sarifu, Seremani, Bakari, Sarifu and Saidi, which are derived from Arabic. ${ }^{71}$ Like Muslims, the Remba circumcise their sons between seven and fifteen instead of at infancy as would be the case if they were following the Jewish culture. ${ }^{72}$ This makes the Remba "distant descendants of the Muslims who got 'cut off' from the cost by the Portuguese." ${ }^{73}$ As indicated above, the Remba may have helped build Great Zimbabwe, and their presence in the monuments area is marked by the excavated models of circumcised male organs that have been found at the initiation site in the Great Enclosure. The Remba were not necessarily the Great Zimbabwe architects, but may have contributed to its building as did many other groups. ${ }^{74}$

The controversies about Great Zimbabwe did not disappear with the termination of the Arab-Remba intercourse but continued to be imbedded in the colonial discourses of dominance. Colonists failed to acknowledge local acumen even in the presence of obvious local connections exhibited in the similar dwellings visible in the surrounding areas as well as oral traditions. Spirit mediums refused to give up their practices within the complex despite legal ban, which represented the undying African spirit and lack of substitute shrines among the indigenous Karanga people. The traditional connection between religion and politics was clear in that mediums were soon joined by political parties in defying the new authority. This symbiotic relationship between religion and politics in defence of territory (shrine) speaks well of the African discourse. This continued respect for the shrine demonstrated its symbolic meaning to the locals as the abode of their ancestral spirits.

69 Mandivenga, Islam in Zimbabwe, 2.

70 Mandivenga, Islam in Zimbabwe, 30.

71 Hammond-Tooke WD. 1937. The Bantu-Speaking Peoples of Southern Africa. London: Routledge \& Kegan Paul, 82.

72 Hammond-Tooke, The Bantu-Speaking Peoples of Southern Africa, 81-84.

73 Mandivenga EC. 1986. Islam in Zimbabwe: A study of the Religious Developments from the Sixteenth to the Twentieth Century, PhD Diss, University of Aberdeen, abstract.

74 Parfitt T. 2000. Journey to the Vanished City. New York: Vintage Random House, 1-2; Mufuka K. 1983. Dzimbahwe Life and Politics in the Golden Age 1100-1500 AD, Harare: Publishing House; Le Roux M. 2003. The Lemba - A Lost Tribe of Israel in Southern Africa? Pretoria: University of South Africa. 


\section{POLITICAL DISCOURSES OF DOMINANCE}

The Zimbabwean archaeologist Innocent Pikirayi notes that, in the last two decades of colonialism the Great Zimbabwe discourse was influenced a "new antiquarian revisionism, based on what Ian Smith and his apologists thought about the place." ${ }^{75}$ Ian Smith, the last Rhodesia Prime Minister, and his government were bent on maintaining white supremacy through the denigration of everything African. They sought to perpetuate the "Pioneer Discourse"76 by burying heroes of the Pioneer Column ${ }^{77}$ in sacred places including briefly at the Great Zimbabwe monuments. Anthropologist Joost Fontein argues that "the site was appropriated to provide historical and moral justification for the imperial projects." ${ }^{18}$ The monuments had to be physically, psychologically and spiritually sealed off from the locals. Physically, a police post was put in place to bar locals from having their rites and rituals within the monuments area. This practice effectively revised the centuries old religious (spiritual) use of the monuments by the local population, which lasted until the takeover of the country by the Pioneer Column at the close of the nineteenth century. ${ }^{79}$ The successive white regimes put in place legal instruments "protecting" monuments and museums. These instruments were to be administered by an "interested" civil service, which was to disparage the truth that credited the indigenous population with masterminding the construction of the Great Zimbabwe complexes. ${ }^{80}$ Its mandate was to advance the theory of the foreign origins of the monuments to discourage any credit being given to locals for such marvellous precolonial achievements.

\section{Colonialism and nationalism in conflict}

The situation became more acute with the rise of nationalism which took pride in ancient African achievements for inspiration. Africans could no longer stand the psychological trauma of being looked down upon by colonists, especially being dispossessed of their ancient heritage. The first act of defiance was in reclaiming the Great Zimbabwe Monuments through the political movements' nomenclature: Zimbabwe National Party (1961), Zimbabwe African People's Union (1961) and Zimbabwe African National Union (1963).

To strengthen its ideology of white dominance, the colonial regime had two dominant partners helping it communicate an exclusive model. The

75 Pikirayi, "The True Story of Great Zimbabwe”.

76 The "Pioneer Discourse" glorified the colonisation of Zimbabwe by a group of armed volunteers sponsored by Cecil John Rhodes, the British imperial tycoon based in South Africa.

77 "Pioneer Column" is the official terminology used to describe the armed volunteers who occupied Zimbabwe at the behest of Cecil John Rhodes.

78 Fontein J. 2006. The Silence of Great Zimbabwe: Contested Landscapes and the Power of Heritage. Harare: Weaver, 213.

79 Matenga, "The Soapstone Birds of Great Zimbabwe”, 123-131.

80 Garlake, Great Zimbabwe: New Aspects of Archaeology. 
most enduring partner was education, closely connected with the Christian missionaries, who formed the other pillar of the colonial regime. The missionaries were clear that outside the church there was no salvation. ${ }^{81}$ The practice of the African indigenous religion at the monuments would be both misleading and non-salvific. Church doctrine left no room for the traditional use of the monuments. In fact, to complement the authorities who built a police post and placed dogmatic civil servants at the monuments site, the church built a large mission at Mogenster overlooking the ancient site. ${ }^{82}$ This was replicated in other places. The famous historian of central Africa, Terence O Ranger, has noted that: "After many years of unsuccessful mission work in the Matopos, the Christian church at Hope Fountain decided to conduct its services at sacred sites including Silozwane national monument that is also near Old Bulawayo another heritage site in an attempt to discredit their use by the local people." ${ }^{83}$

In its exclusive approach, the church further advanced the notion of being chosen in relation to the Jews - and Christians by extension. ${ }^{84}$ The theory of election with its resentment for everything African led to an unnecessary assault on the local culture. The church offered the Western version of the JudeoChristian tradition as an alternative to the local culture which was described as heathenism. The term "Judeo-Christian" refers to "the influence of the Hebrew Bible and the New Testament on one's system of values, laws and ethical code". 85 In the Black and White paradigm, the African ways represented the former while the later signified Western civilisation. Christian villages were built to wean Africans from their heritage. Gokomere Mission, forty kilometers north of Great Zimbabwe, and, to a lesser extent, Mogenster provide good examples. ${ }^{86}$

\section{The Solomonic legend and the Abrahamic religions}

The missionaries further hoped to appropriate the African heritage through the Solomonic legend. The idealistic search for the historicity of Solomon's gold mines at Ophir led a member of the Berlin Mission Society, Rev A Merensky, to direct Karl Mauch to Great Zimbabwe on a verification mission and he straightaway appropriated the structures to the Semitic people. ${ }^{87}$ Between

81 Knitter PF. 1985. No Other Name? A Critical Survey of Christian Attitudes Toward the World Religions. New York: Orbis, 121.

82 Mawere, Sagiya and Mubaya, "Convergence of Diverse Religions", 23.

83 Ranger TO. 1999. Voices from the Rocks: Nature, Culture and History in the Matopo Hills. Harare: Baobab, 150. "Another heritage site" here refers to "Old Bulawayo" - all quoted.

84 Banana CS. 1996. Politics of Repression and Resistance: Face to Face with Combat Theology. Gweru: Mambo; Isabel M, Cox JL and Verstraelen FJ (eds). 1993. Rewriting the Bible: The Real Issues. Gweru: Mambo.

85 Lee R. 2009. "Seven Principles of the Judeo-Christian Ethic", The American Patriot's Bible. Nashville, TN: Thomas Nelson.

86 Zvobgo CJM. 1996. A History of Christian Missions in Zimbabwe 1890-1939. Gweru: Mambo.

87 Carroll, "Solomonic Legend", 236. 
1873 and 1876, an interested European press enthusiastically spread the news of Mauch's speculation about Solomon's presence at Great Zimbabwe. Literary works including Hugh Mulleneux Walmsley's The Ruined Cities of Zululand and Rider Haggard's King Solomon's Mines wetted the appetite of the European audience for success stories of European adventures, while making the subsequent African literature student of the colonial Rhodesia hate or feel uncomfortable with his/her past. ${ }^{88}$ By the end of the nineteenth century, the reign of Solomon at Great Zimbabwe had been accepted as proven; and thus "fiction and popular notion had been mistaken for fact". ${ }^{89}$

The Judeo-Christian template not only excluded the Africans and their religion from the monuments, but also negated any other tradition contrary to the propagation of the Christian appropriation of the Jewish Messianism through Christ. In this regard, Muslims, who equally deny the divinity of Jesus Christ, could not have anything to do with the magnificent monuments. Christians "quoted" Muslims as denying any involvement in the monument construction which they attributed to Solomon. ${ }^{90}$ The authenticity of these quotations is doubtful since they were written by Christians in an atmosphere of ChristianMuslim competition. The Portuguese were the first to use the technique of forged Muslim quotations in the mid-sixteenth century and this spread to other Christian nations uncritically. ${ }^{91}$

Missionaries also used education to concretise their model, which essentially meant appropriating Western Christian values exclusive of any other "salvation and progressive model". Those who dared challenge this model by words or action risked dismissal in some instances. ${ }^{92}$ This dominant discourse that advanced Jewish-Christian superiority and damaged the Remba cultural heritage leaving them with disputed paternity. ${ }^{93}$ To fit into the dominant discourse, the Remba close to the monuments claim Jewish ancestry, while some members of the same Remba group residing in Gutu District in eastern Zimbabwe have long embraced Islam leading to the building of a mosque and employment of a professional Muslim imam. Currently plans are afoot to build the Great Zimbabwe Synagogue among the Remba of Tadzembwa close to the

88 Walmsley HM. 1869. The Ruined Cities of Zululand. London: Chapman and Hall; Haggard R. 1885. King Solomon's Mines. London: Thomas Nelson and Sons.

89 Carroll, "Solomonic Legend", 236.

90 De Barros J. 1964. "Da Asia", in Theal GN (ed). Records of South-Eastern Africa, vol. VI. Cape Town: Printed for the Government of the Cape Colony, 267-268.

91 Carroll, "Solomonic Legend", 243

92 Teachers were dismissed for marrying more than one wife.

93 Historians David N Beach and Stan Mudenge and Islamic scholar Ephraim Chikakano Mandivenga argue that the Remba circumcision rituals, marriage and dietary laws reflect Muslim heritage acquired as a result of Arab-Shona intermarriages in the Zambezi valley. Even Tudor Parfitt's genetic theory does not exclude Islamic heritage, as he agrees that the Jews and Arabs of Hadramaut in Yemen have similar genetic configurations. Some Remba today accept Islamic heritage, while others claim Jewish origins leaving the tribal group with disputed paternity. 
Great Zimbabwe Monuments. The synagogue issue has been necessitated by a sense of belonging. This is particularly so because, by the time the discourse reached out to the Remba, the majority of them were already Christian. ${ }^{94}$

Tudor Parfitt, a British anthropologist born in Wales and bred in England from a non-Jewish family with "an intense admiration for Jewish people", has travelled to the remotest regions of the world looking for the "lost tribes of Israel" ${ }^{95}$ Parfitt supports the Jewish theory, regarded as fallacious by a number of local scholars, including David N Beach, Ephraim Chikakano Mandivenga and Stan IG Mudenge. Parfitt advanced a genetic theory which gives the Remba a genetic configuration similar to that of the Jews. He argues that they must have moved from Yemen as a group into Africa. This assumption is problematic because in that case they should have had both male and female genes similar to those of the Jews. Since they have only the male gene in common he has proposed another assumption in which a lone Jew unknown in history must have strayed into East Africa and left children there. This assumption is complicated by the fact that the Arabs in the region of Hadramaut, the postulated region of the "original Sena," have a similar genetic configuration. Moreover many Arabs from the region were in the vicinity of the Great Zimbabwe area, as confirmed by the presence of many artefacts. The Remba also use Arabic and not Jewish names and the marriage and food taboos in question bridge two of the Abrahamic religions: Judaism and Islam.

The proposed Jewish linkage may therefore be an unstable tradition. The British historian Eric Hobsbawm, in discussing invented traditions, notes that "where possible, they normally attempt to establish continuity with a suitable historic past ... However, insofar as there is such reference to a historic past, the peculiarity of 'invented' traditions is that the continuity with it is largely fictitious." 96 Hobsbawm further argues that "many practices which are considered traditional are in fact quite recent inventions, often deliberately constructed to serve particular ideological ends." ${ }^{\prime 97}$ The Jewish link is ideologically linked to the Judeo-Christian template.

94 The authenticity of Remba religious heritage took a sharp turn in 1961 when Muslims took an active role to (in Ephraim Mandivenga's terminology)"reIslamise" the Remba by building mosques and "re-teaching" them Islamic principles. By then many of them were already Christians and reluctant to "rejoin" Islam.

95 Online at: www.miamherald.com/2013/05/3389721/religious-studies-professoris.html

96 Hobsbawm E. 2004. "Introduction: Inventing Traditions", in Hosbawm E and Ranger T (eds). The Invention of Tradition. Cambridge: Cambridge University Press, 1.

97 Yee D. 1995. “A Review of The Invention of Tradition by Eric Hobsbawm and Terence Ranger (eds), Cambridge University Press, 1992". Online at: http:// dannyreviews.com 
The Ngomalungundu (the drum that thunders), which Parfitt likens to the Ark of the Covenant, ${ }^{98}$ further complicates the authenticity of his argument. The latter posits a lone Jewish ancestor and negates the former theory of the Exodus from Jerusalem with the Ark of the Covenant via Yemen with the subsequent imitations. To say that the drum which has nothing real in common with the Ark of the Covenant except the method of carriage is its replica baffles the mind. The biblical Ark of the Covenant was not a thundering drum. It was the trumpet that sounded and not the Ark of the Covenant. But this claim has resulted in the construction of synagogues in Mberengwa, "the spiritual home of all the Lembas", 99 along with one being proposed in the Great Zimbabwe region. The trend in Mberengwa, though, has been that only those interested in Judaism as "one of the churches", including non-Remba, go to the synagogue. ${ }^{100}$ The Jews, however, are not allowed in the Remba initiation venues and are not considered legitimate ritual slaughterers by the majority of the Remba, ${ }^{101}$ though Remba culture has come to be managed through a Judeo-Christian template.

By managing the Remba cultural heritage through the Judeo-Christian template, Christians have sown confusion in the Remba ranks. Their aim of discrediting any competing religion has left the Remba with a disputed paternity and in danger of being declared foreigners in their land of birth. Yet in the Shona context, a cousin can actually take over the traditional leadership of his mother's people. If the carvings representing circumcised manhood were made at the behest of the Remba, then they have been lost to the Great Zimbabwe Museum just as the Ngomalungundu which now lies in a Harare museum. ${ }^{102}$ The Remba do not benefit from such displays which have been deprived of all religious connotations.

\section{LEGAL PROTECTIONS AND CHALLENGES IN HERITAGE MANAGEMENT}

The Great Zimbabwe site has been legally protected since 1893 and is currently protected under the National Museum and Monuments Act Chapter 25:11 (1976), which provides for the legal protection of the resources within the property. ${ }^{103}$ The Act does not define the role to be played by local authorities,

98 The Ngomalungundu is a drum which was also used in sacred performances by the Remba.

99 Mativha MER. 1992. The Basena, Vamwenye, Balemba. Johannesburg: Morester, 47.

100 Mariposa Tavengwa, a Remba who goes to one of the synagogues says only those Remba interested can come since it is just one of the "churches" which even accepts senzi (non-Remba as in gentiles). The impression from this Remba elder implies that importance is placed on conversion and not heritage.

101 Interview with Maramwidze Tadzoka by E Dube, Danga-Mposi, Zimbabwe 22 April 2016.

102 Parfitt T. 2002. “The Lemba: An African Judaising Tribe”, in Parfitt T and TrevisanSemi E (eds). Judaising Movements: Studies in the Margins of Judaism. London: Routledge Curzon, 40-42.

103 Mawere M, Mubaya TR and Sagiya ME. 2013. “Challenges, Dilemmas and Potentialities for Poverty Relief by Heritage sites in Zimbabwe: Voices from 
and the ambivalence in this area creates problems for heritage management, especially with regards to determining the relevant stakeholders for the smooth management of both tangible and intangible heritage. The Act affects the traditional interaction between the heritage site and the local community as the legal implementation is more skewed against the indigenous involvement. The monuments were adopted as a UNESCO World Heritage Site in 1986, implying their outstanding universal value. It was one of the most significant civilisations of the medieval period, ${ }^{104}$ and one of the only seven in southern Africa to be accorded such respect by UNESCO. Nevertheless, even with the UNESCO World Heritage Site designation, management of the Great Zimbabwe monument site has not been without challenges.

The first challenge is to address is the question: For whom should heritage be managed? Heritage management specialists Munyaradzi Mawere, Tapiwa Mubaya and Munyaradzi Sagiya argue that "the use of heritage sites should be compatible with culture of the people in which the site is located, that is, the use of the sites should respect the cultural significance of a place." ${ }^{105}$ But the foregoing discussion has shown that once the Pioneer Column established company rule in what was then Rhodesia, the Great Zimbabwe Monuments became part of the establishment to the exclusion of the indigenous people. ${ }^{106}$ This suggests that the adoption of Western formal legislation has had the effect of alienating the local people from the administration of their natural and cultural heritage. ${ }^{107}$

A new appropriation theory was invented in the name of the exotic origin of the monuments. Was this exclusive model fair if the Afrocentric view of the local origins is correct? The function of the place changed from sacred site to tourist centre, which further excluded the locals since they could not afford the fees. It is difficult for the descendants of the builders of the structures to accept the ban, while those with money marvel at what should be their rightful inheritance. This top-down management approach transfers all benefits to the controlling authority. Instead, the bottom-up approach would have allowed the locals to benefit, while the authorities reaped the taxes.

The political parties used the monuments as an inspirational past achievement, and now the country has its very name derived from the Great Zimbabwe monuments. The liberation discourse nationalised the monuments and at

Chibvumani Heritage Site Stakeholders", Journal of Sustainable Development in Africa 15(1):193.

104 Ampim, "Great Zimbabwe: A History Almost Forgotten".

105 Mawere, Sagiya and Mubaya, "Convergence of Diverse Religions", 29.

106 Mawere, Mubaya and Sagiya, "Challenges, Dilemmas and Potentialities", 187-188.

107 Ndoro W and Kiriama M. 2008. "Management mechanism in Heritage Legislation", in Ndoro W, Mumma A and Abungu G (eds). Cultural Heritage and the Law. Protecting Immovable Heritage in English Speaking Countries of Southern Africa. ICCROM Conservation Studies 8, 54. 
independence they continued to be controlled by national codes through 1986, when UNESCO codes were also extended to the monuments as a World Heritage Site. ${ }^{108}$ These legal regimes have not done better in the restoration of the colonial dispossessions. Heritage management is still done for purposes contra enhancement of local needs. Those with the political muscle utilise the venue without hindrance, thus war veterans from the Harare province brought with them Mashonaland regional mediums Nehoreka and Bhasvi in March 2011 and held their ceremony uninterrupted, and yet ordinary people have to conjure means to enter the monuments area for similar performances. ${ }^{109}$

\section{CONCLUSION}

Colonial discourses have negatively affected the ownership and use of both the tangible and intangible heritage at Great Zimbabwe. The colonial government appropriated the monuments and assigned them foreign origins which abrogated the claim to ownership and use by the indigenous people. The "authorised heritage discourse syndrome" 110 did not allow the attribution of any kind of heritage associated with the monuments to its indigenous authors and owners. Laws were crafted specifying the colonial authorities as stakeholders, but they were silent about the place of the indigenous people. Implementation, however, clearly excluded the indigenes. But issues associated with religion do not easily succumb to legal frameworks. For that reason, Great Zimbabwe remains the spiritual home of indigenous aspirations, to the extent that political parties were named after the monuments in the midst of the harsh apartheid laws advocating separate progress for different races. The monuments continued to inspire various spirit mediums from across the country through the colonial, liberation and post-independence periods.

Independence did not bring legal revision and the locals have remained peripheral to the management and use of heritage associated with Great Zimbabwe. Since the nationalisation of the monuments by the colonial government in 1937, they have never reverted to local use - with the result that spiritual use at political or national levels has remained more tolerable to this day than local use. The "authorised heritage discourse syndrome" augmented by the "Judeo-Christian template" has struck a wedge in the Remba cultural heritage leaving them with a disputed paternity; split between Muslim and Jewish fatherhood. The foundations of the Great Zimbabwe Synagogue are currently being laid, even though similar endeavours in Mberengwa have neither attracted committed Remba Christians to synagogue, nor integrated Jews into the Remba cultural milieu. Failure has been the result. Those who

108 Mawere, Sagiya and Mubaya, "Convergence of Diverse Religions", 23.

109 Mawere, Sagiya and Mubaya, "Convergence of Diverse Religions", 23.

110 Matenga, "The Soapstone Birds of Great Zimbabwe". The term "authorised" indicates that heritage officials had no leeway to digress from the official position even though they knew its flaws. 
maintain the Jewish discourse have had a problem of "telescoping", that is, projecting events too far into the past. As it is, no artefacts discovered at the monuments reflect any period span by the Jewish empire, clearly dissociating the Jewish empire from the Great Zimbabwe Empire.

Successive governments have adopted Western formal legislation which has alienated locals from the administration of their heritage sites. The net result of this has been to put heritage managers in an awkward position, speculating what their actual role should be vis-à-vis what the law says in relation to the realities on the ground. Locals struggle against the law to have access to what is theirs for their own religious enhancement against uncooperative successive political authorities. The government as the legislature- and law-enforcing agent, the local indigenous believers and the Christian exclusivists are locked in endless arguments over the utilisation of the monuments. All these currents make life difficult for the conservationists who value local input as a management tool. Very often heritage managers have advocated for dialogue amongst the competing voices. ${ }^{111}$ Closing out locals has been of particular concern to the heritage managers, since the locals are the owners of the heritage. There is a need to re-align the heritage laws in order to re-integrate the locals into the management systems of the heritage sites. This is important because, although this chapter focuses on Great Zimbabwe, the situation obtaining here may be true for all other heritage sites in Zimbabwe.

111 See the following works by monuments and former monuments staff. Mawere, Sagiya and Mubaya, "Convergence of Diverse Religions", 22-31; Mawere, Mubaya and Sagiya, "Challenges, Dilemmas and Potentialities", 186-198; Matenga, "The Soapstone Birds of Great Zimbabwe". 